\title{
Analysis on the Present Situation of College Classroom Management and Its Countermeasures
}

\author{
Zhenglei Dong \\ Huanghe Science and Technology College \\ Zhengzhou, China
}

\begin{abstract}
Classroom teaching is the most important part of education. The quality of classroom management directly influences the final effect of classroom teaching. Classroom management is a process that teachers can effectively achieve the desired goals by coordinating various external factors. This paper takes improvement of classroom teaching of art colleges and universities as the starting point, discusses and analyzes the effective ways of college classroom management, expects to make the classroom management more and more perfect.
\end{abstract}

Keywords-art college; classroom management; effective way

\section{INTRODUCTION}

In the early 90 s of last century, China's higher education has entered a period of vigorous development, higher education enrollment makes more and more people have the opportunity to receive higher education. In 2015, the number of college students in our country has exceeded 30 million, and our country has made great changes in the improvement of educational hardware facilities and the investment of funds, our country has actually entered the ranks of higher education big country. The most important link in all aspects of university education is classroom teaching, it is the main channel to acquire knowledge, so only from the teaching level began to reform, then it will be able to create a new "learning community", complete the mission and responsibility of higher education in a higher standard, and ultimately achieve the change from big education country to powerful education country.

\section{THE IMPORTANCE OF CLASSROOM MANAGEMENT}

In the colleges and universities, good classroom management can effectively form a harmonious and positive classroom learning environment, which can stimulate students' enthusiasm for learning, improve learning effect and teaching efficiency, also promote the teaching activities to be carried out smoothly and effectively. At present, the level of teaching quality and classroom teaching efficiency have a more direct relationship which will have a certain impact to the sustainable development of colleges and universities. Nowadays, China's higher education has changed from elite education to mass education, from small class teaching to large class teaching. However, teaching methods and teaching contents still follow the traditional teaching mode, which leads to the emergence of some problematic behavioral problems and brought some new challenges to classroom management. To this end, face this situation, colleges and universities strengthen classroom teaching management is imperative, in order to improve teaching efficiency and improve learning results.

Classroom teaching management refers to teachers' some classroom management activities besides the teaching tasks, the main purpose of classroom management is to help teachers and students to create a good teaching environment and learning environment, so that can effectively coordinate teacher-student relationship and improve students' learning enthusiasm. Nowadays, students often sleep, play mobile phone, and talk in the classroom. Some students even directly have conflicts with teachers because of dissatisfaction with teachers' management, and also they are late for class, leave early, absent, poor discipline and other problems emerge in an endless stream. Therefore, it is necessary to manage the classroom teaching, and strive to establish a good classroom teaching and learning environment, to promote learning consciousness in order to successfully complete the task of teaching and achieve classroom teaching goals and improve learning efficiency. It can be said that the management teachers in colleges and universities not only the instructor of teaching activities, but also classroom managers.

\section{THE CURRENT SituAtion OF UNIVERSITY SUBJECT MANAGEMENT IN THE NEW ERA}

\section{A. (1) Teachers' Lack of Understanding of Classroom Management}

After the enrollment expansion of higher education, a large number of young teachers have entered the university for classroom teaching, these teachers gradually become the main force of higher education. Although many teachers are knowledgeable, experienced and teaching seriously, but many colleges and universities' teaching achievement is not obvious. The main reason is that these teacher is only too much emphasis on the curriculum teaching, ignoring classroom management, they carefully prepare the lesson and teaching with patient ,but in the classroom the students do not have the patience to learn, the ultimate learners and teachers can not achieve parity, resulting in teaching quality decline. These young teachers have passion also have rich teaching experience, but due to classroom management negligence, leading to low classroom efficiency. 


\section{B. Classroom Management Failed to Form A Perfect System}

It is the classroom management system to guarantee the teaching objectives and teaching quality in colleges and universities. However, in the reform of colleges and universities in our country, it only gathers in teaching contents and teaching methods. It can be said that the reform of classroom management in our country is slow, even stagnant. Lack of validity and scientificity in the system design. The system of classroom management in colleges and universities is not only disorderly, even some conflicts appeared too, and it does not regulated with the new situation and new problem happened with China's higher education. In addition, the design concept of the classroom management system is lack of humane care, teaching objectives are old and even some ambiguities appeared.

\section{Mobile Internet Access to College Classroom}

The emergence, popularity and coverage of Mobile Internet terminal equipment and wifi make them quietly access to the classroom. In classroom, each student has a smart phone, they check Weibo, Tieba, check the moments on Wechat, chat with friends on class, this phenomenon appears in each university classroom. Today, the mobile phone has transitioned from the vehicle to the necessities, for students the class can go without textbook, notebook or pen, but it can go without mobile phone. And, as smart phone get more and more advanced, only few notes were taken down in class, when the teacher said courseware emphasis, students take a lot of picture instead of taking notes.

\section{THE REASON OF THE EMERGENCE OF MANAGEMENT STATUS}

\section{A. Weak Awareness, Obsolete Concept}

Teaching classroom is the main channel for the dissemination of knowledge, but only conduct teaching activity mechanically for knowledge transmission, it can not achieve good teaching effect or pass the knowledge to students effectively. Generally speaking, in the college classroom, the teacher is only teaching knowledge but makes few communications with students, even pays no attention to the students' acts, lack of motivation and vitality. Formation of this situation is mainly because teachers' lack of corresponding teaching philosophy, lack of understanding of the "student is the main subject of teaching", "student-centered" teaching ideas, lack of ideological change, obsolete teaching philosophy, and thus leading to the neglected students management in classroom management.

\section{B. Angular Management Methods}

In college's classrooms, teacher is the direct management and implementer of the classroom, but the phenomenon of students disturbing the classroom order often occurs, for this problem the students' management methods are angular. After investigation and analysis, most teachers directly use the criticism education method for students who disrupt classroom order, pointing out the shortcomings of the students in the classroom, and educating them, but this method does not achieve good results, and this management is simple, crude, lack of management method innovation.

\section{Lack of Interaction, Teacher-Student Relationship Is Not Harmonious}

Through the survey, most students reflect the teaching content in classroom is boring, teaching effect is low, students' enthusiasm to participate in classroom teaching is not high. For teachers, in order to save effort, teachers often ask students with good grades, very rare to ask students with poor grades. Therefore, only a small part of the students in the classroom to play the subjectivity, most of the subjectivity did not well played, the interactions between teachers and students became the interactions between a few people, and ultimately lead to classroom teaching shows the phenomenon of "you do not like to learn, I do not like to teach ", and both teachers and students will issue the same complaint which resulting in teacherstudent relationship is not harmonious.

\section{STRATEGIES OF UNIVERSITIES TO IMPLEMENT EFFECTIVE ClassRoOM MANAGEMENT UNDER THE NEW PERIOD}

\section{A. Change the Old Teaching Management Concept}

Nowadays, the lack of understanding of classroom management in the classroom teaching requires the change of old teaching management concept, enhance teachers' understanding of classroom management and the improve the classroom management level. First of all, teachers should recognize that the classroom is not only a place for teaching, but also a place for communication between teachers and students. Classroom should not be a place of knowledge exchange, it is the spirit homeland of the students, is the place for them to explore the production culture.

For that reason, in the new period it requires teachers not only need to teach theoretical knowledge but also need to communicate with students in the classroom, so that students take the initiative to participate in classroom teaching. Both teachers and students together write a beautiful music. Therefore, in classroom teaching, teachers should give adequate attention to classroom management, improve classroom management ability. Specifically, they could strengthen the communication with students in classroom and make full use of the "first effect" in teaching process, the design of the first lesson should be ingenious in order to lay a good foundation for the future teaching communication.

\section{B. Use Rational Attitude to Mobile Internet}

The emergence of mobile Internet has an enormous impact for college students, blindly forced to stop is not feasible, so it needs to take a rational attitude to guide. Such as: some university in order to restrict students to play mobile phones in class, improve classroom efficiency, teachers set up a "phone box", let students put their phones in the box willingly before the class and return them back after class. At first there only a few students willing to put their phones in, but later most students put in, even a few students feel that others have put, if they did not then it will loose face, so they all put their phones 
in the box. This action let students have their willing choices, they fee respected so it achieved better results. In addition, some colleges and universities take an external signal shield device, this mandatory approach is only temporary solution but not a permanent cure, and it will increase the students' negative mentality without good results. To solve this problem, first of all, students should enhance the recognition consciousness of the internet, let them use the internet rational, so that students will shield mobile internet from the psychological, and then can improve classroom management effect.

\section{Strengthen the Self-Management of Students}

Classroom management only depend on teacher alone is obviously not enough, it needs the help of teachers and students together to achieve the corresponding effect. First of all, classroom management should improve the autonomy of students, teachers should help students to develop their learning plans and career planning, so that students realize their real purpose to the university. On this basis, students develop their own detailed management planning, teachers in the management process should not only talk about hopes and expectations, but change expectations into specific measures to enhance students' internal driving force for self-management. Teachers as knowledge sender and guider, they need to help others to implement management planning, supervise the implementation, and thus improve the ability of selfmanagement. At the same time, teachers should give students full respect, believe that students have the ability to implement their own self-management, hand down the right of classroom management to students, so that students themselves could really participate in their self-management, and then improve classroom management efficiency.

\section{Establish A Good Teacher-Student Relationship}

The foundation of classroom management order is the good teacher-student relationship. Based on the field of education, many colleges and universities in our country have caused a difficult internal conflict because of the poor relationship between students and teachers. Therefore, teachers should give students full respect and trust their students, avoiding taunting or punishing them. Good teacher-student relationship is not built on the blindly compromise on one side, but on the communication to solve the problem, and make common progress. In view of this, the classroom discipline problem is inevitable and unavoidable, no one is perfect. So when these problems happened, teachers and students should stand on each other's side to think about the problem, I respect you, I also hope you respect me, because respect is mutual, teachers and students should communicate on the basis of equality. If the problem is handled improperly, it will increase the student's negative mentality.

Specifically speaking, the construction of a reasonable teacher-student relationship requires teachers to give full recognition, respect and trust to students, avoid excessive discourse and give the students a positive guidance, tell them what you can do, not what I can help you to do, and actively guide students to the right direction so as to help them make progress. Students will put aside their wariness when they felt the real concern from their teachers, then they will defend their teachers and not violate the classroom discipline, thus the classroom order is bound to improve.

\section{CONCLUSION}

To sum up, strengthen the classroom management is the foundation to effectively improve the teaching effectiveness. With the development and progress of the times, the university classroom management will also appear new problems. In this case, how to take effective measures to strengthen classroom management and achieve good teaching results, is the issue both teachers and students should actively explore.

\section{REFERENCES}

[1] Chen Shijian. "Classroom management: meaning and change" [J] Educational Science Research, 2003 (6).

[2] Xiao Chuan. "Teaching design of Chinese famous teacher" [M]. Popular Literature and Art Publishing Company, 2010.

[3] Chen Shijian. "Classroom management theory" [M]. Guangxi Normal University Press, 2002.

[4] Feng Jianguo, LI Guihua, Wei Jiuchuan. "The Problems and Countermeasures of Classroom Teaching Management in Universities" [J]. China Electric Power Education, 2011 (35).

[5] Ke Yinghui. "Study on the Countermeasures of Teaching Management in Colleges and Universities" [J]Journal of Huaihai Institute of Technology (Social Science Edition), 2011, (11)

[6] Lv Yangfen. "Classroom management reform and innovation" [J]; Journal of Liaoning Teachers College (Social Sciences Edition), 2005 (2) 